\title{
Naming Consistency for Forest Plants in some Rural Communities of Northeast Thailand
}

\author{
Lyndon Wester and Sekson Yongvanit
}

\section{Research}

\begin{abstract}
Consistency of naming forest plants was subjected to a field test in a rural community of Northeastern Thailand. Local experts supplied names for a set of trees and vines in a surveyed plot. Results showed a high level of agreement among the informants for more than half of the plants and less than $10 \%$ of the plants were not named consistently by the majority of informants. Disagreement on names largely took the form of non-responses or degrees of specificity. In general, vines and immature understory plants produced the greatest diversity of opinion. Of the names collected, $53 \%$ were recorded in standard botanical references but about half were linked with more than one Latin binomial, often in different families. Many false links could be quickly resolved if voucher specimens of the plants were compared with herbarium specimens.
\end{abstract}

\section{Introduction}

The only real determinant of "correctness" in the use of a common name for a plant is if it communicates information accurately. A "correct" name therefore is one that any group of people agree to and use consistently to identify an object. However, outside of that specified cultural context, the name may have no meaning, or worse, may inadvertently convey incorrect information, if the same word has been attached by another group of people to a different object.

In a large and culturally diverse region as Thailand, now with a highly mobile population, the possibility for confusion in the use of common names is great. The scientific binomial system solves the problem of cultural and linguistic context by referring a Latin name to an actual type specimen or detailed written published descriptions of it. However, even if a local name of an individual plant can be validly linked to a Latin binomial, there is no assurance that the two name categories have exactly the same scope of meaning. Nevertheless, local plant experts are commonly used to assist in ecological or ethnobotanical field surveys to help differentiate taxa.

The question of the consistency of application of local names, and the equivalency of local names and Latin binominals, was subjected to a field test in a forest plant community in Northeastern Thailand. Studies elsewhere have shown that there is often a broad level of agreement between indigenous and scientific naming systems, although the indigenous systems may make finer distinction among plant groups that are of cultural importance (so called "over differentiation") or fewer distinctions for those that are less valued ("under differentiation") (Berlin 1992, Martin 1995). However, the primary purpose of this study was to compare plant identifications of several local experts under typical, but less than optimum conditions, and to establish the amount of agreement on local names of particular plants within one rural community. Furthermore, the study provides a basis for discussing the frequent practice of taking names supplied by local informants and attempting to link them to Latin binomials listed in standard published reference works.

\section{Correspondence}

Lyndon Wester, Department of Geography, University of Hawai' i, 2424 Maile Way, Honolulu, Hawaii, 96822, U.S.A.

wester@hawaii.edu

Sekson Yongvanit, Faculty of Humanities and Social Science, Khon Kaen University, Khon Kaen, 40002, THAILAND.

sekyon@kku.ac.th

Ethnobotany Research \& Applications 4:203-212 (2006) 
Voucher specimens of selected plants were taken for independent identification by a botanist trained in the Linnean system to compare the level of agreement with names supplied by the local informants. The plants that are the subject of this study represent what one might realistically encounter in an ecological or ethnobotanical field study. These are not plants that necessarily possess the most desirable diagnostic parts for identification but are the plants one would find in any random plot of forest with specimens that included individuals in different stages of maturity as well as suppressed by competition in the understory.

\section{Methodology}

The study site was a forest of mixed evergreen and deciduous species in Northeast Thailand. The region had been selectively logged in the 1970's and there had been seasonal camps near the site at least since 1945 but no permanent village until 1972 (Yongvanit \& Thongchan 1993). The survey plot was located near a temple, which probably gave it more protection from human disturbance than the fact that it was in a forest reserve. Nevertheless, it would still be classified as a significantly disturbed and degraded forest community (Wester \& Yongvanit 2006).

\section{Selection of Informants.}

Members of local communities identified eleven herbalists as experts; none were self defined (Table 1). All were from different villages and tambon (village clusters) scattered over three different amphur (counties) and all but one lie adjacent to the border of Kalasin and Khon Kaen provinces. The exception was one informant who was from a village in amphur Khon Sarn, Chaiyaphum province, located more than 200 kilometers away from the other villages. All the informants were male and practicing herbalists, either for their family or the community, or herb collectors who gather plant material for wholesalers as a source of income. Their ages ranged from 52 to 85 with a median age of 70. All informants were Thai nationals but ethnically Lao (Isaan) and would have learned the local dialect as their first language. Although Thai and Lao are generally regarded as regional dialects, a speaker of only one language often has great difficulty understanding the other.

\section{Field Identification Survey.}

A transect $50 \times 10$ meters was surveyed and the dimensions and location of all trees and vines over two meters tall were recorded and tagged. Each informant was taken to the site independently and asked to identify and name each of the surveyed trees or vines. If the informants were aware of more than one name for any particular plant, they were asked to supply it. All communication and data recording was done in Thai or Lao and names were recorded in Thai script.

Voucher specimens were collected for all of the taxa named by informant " $A$ " and were identified as precisely as possible with the assistance of a Linnaean botanist with much experience in Thai forests and with reference to material in Chiang Mai University herbarium.

\section{Results and Discussion}

A total of 96 plants in the forest transect were the basis of this study. Most of the informants supplied names for more than $50 \%$ of the plants. Although one informant could name only $37 \%$, another supplied a name for all of them (Figure 1). In all, 77 different names were used by informants and are listed in Table 2. Although informants were asked to be as specific as possible when supplying names, the responses are clearly a mixture of primary names, such as wa (which in Thai generally refers to genus Sygyium), and secondary names, consisting of a primary name with a more specific modifier, such as wa khao meaning "white Sygyium" (Table 3). In this study, if there is agreement among informants at the level of the primary name, this will be specified. Otherwise, agree-

Table 1. List of Informants.

\begin{tabular}{|c|c|l|l|l|l|}
\hline INFORMANT & AGE & PROVINCE & AMPUR & TAMBON & OCCUPATION \\
\hline A & 85 & Chaiyaphum & Khon sarn & Nam Um & Herb collector and herbalist \\
\hline B & 52 & Khon Kaen & Kranuan & Huai Yang & Village head man, herbalist \\
\hline C & 70 & Kalasin & Thakantho & Kung Kao & Herb collector and wholesaler \\
\hline D & 60 & Kalasin & Thakantho & Kung Tao & Farmer, herb collector \\
\hline E & 72 & Kalasin & Thakantho & Natan & Herb collector and herbalist \\
\hline F & 78 & Kalasin & Nong krung si & Dong Mun & Herb collector and herbalist \\
\hline G & 68 & Kalasin & Thakantho & Na Taln & Herb collector and herbalist \\
\hline H & 70 & Kalasin & Thakantho & Kutjik & Herb collector and herbalist \\
\hline I & 70 & Kalasin & Nong krung si & Nong Yai & Farmer, herb collector, herbalist for family \\
\hline J & 53 & Kalasin & Nong krung si & Koko Kuer & Farmer, herb collector, herbalist for family \\
\hline K & 68 & Kalasin & Nong krung si & Kut Kaeng & Herb collector \\
\hline
\end{tabular}




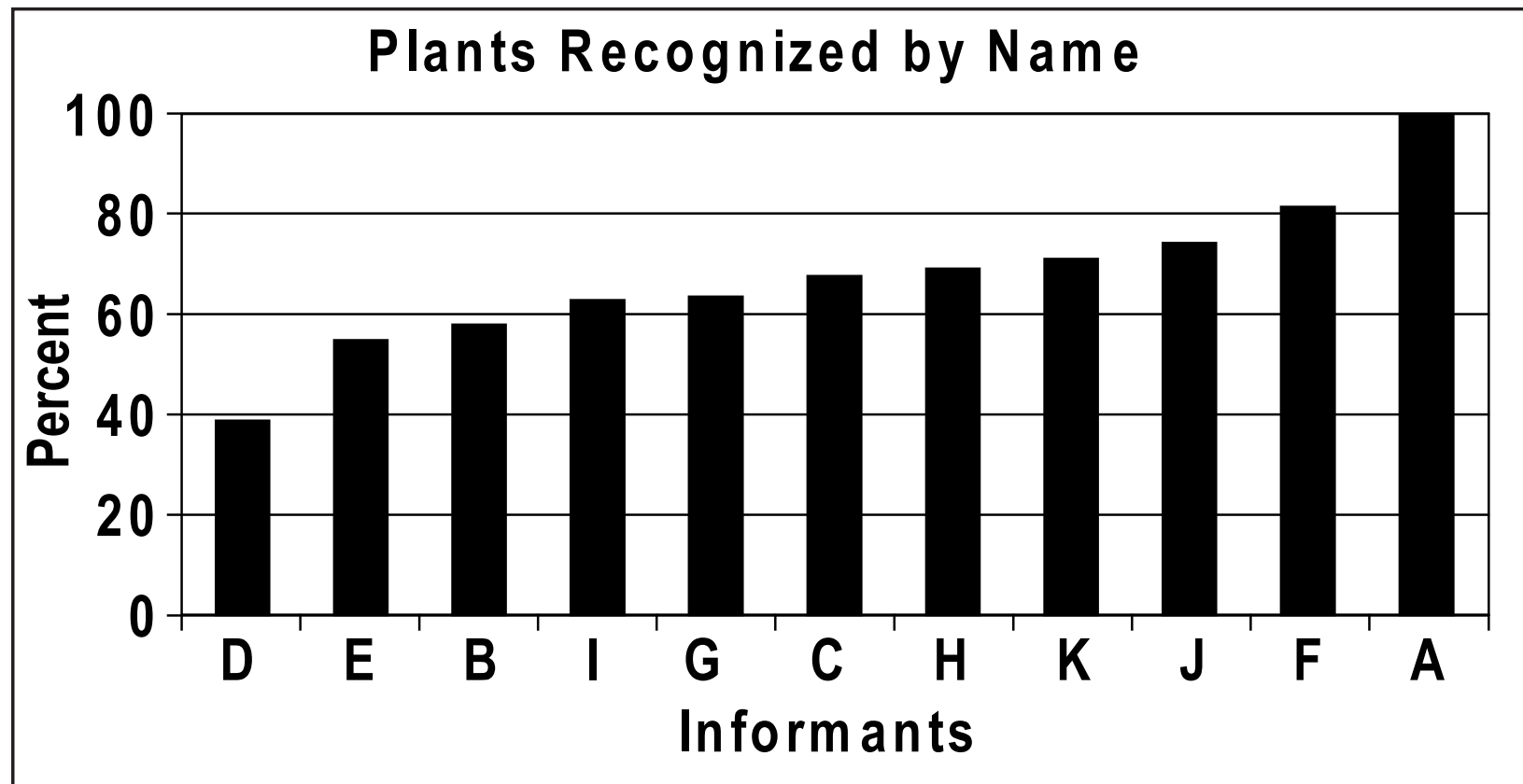

Figure 1. Ability of informants to name ninety six plants.

Table 2. List of plant names that were used by informants.

\begin{tabular}{|c|c|c|c|c|c|c|c|c|c|c|c|c|c|c|}
\hline \multirow[t]{2}{*}{ PLANT NAME } & \multicolumn{11}{|c|}{ INFORMANTS } & \multirow[t]{2}{*}{ TOTAL } & \multirow[t]{2}{*}{ Binomial $^{1}$} & \multirow[t]{2}{*}{ Families $^{2}$} \\
\hline & A & B & C & D & $E$ & $\mathbf{F}$ & G & H & I & $\mathbf{J}$ & $\mathbf{K}$ & & & \\
\hline khai nao & 1 & 1 & 1 & 1 & 1 & 1 & 1 & 1 & 1 & 1 & 1 & 11 & 4 & 2 \\
\hline khae pa & 1 & 1 & 1 & 1 & 1 & 1 & 1 & 1 & 1 & 1 & 1 & 11 & 4 & 1 \\
\hline mueat ae & 1 & 1 & 1 & 1 & 1 & 1 & 1 & 1 & 1 & 1 & 1 & 11 & 1 & 1 \\
\hline salak dam & 1 & 1 & 1 & 1 & 1 & 1 & 1 & 1 & 1 & 1 & 1 & 11 & 1 & 1 \\
\hline kean tao & 1 & 1 & 1 & 1 & 1 & 1 & 1 & 1 & 1 & 1 & 1 & 11 & 0 & 0 \\
\hline kom som & 1 & 1 & 1 & 1 & 1 & 1 & 1 & 1 & 1 & 1 & 1 & 11 & 0 & 0 \\
\hline ma kha tae & 1 & 1 & 1 & 1 & 1 & 1 & 1 & 1 & 1 & 1 & 1 & 11 & 1 & 1 \\
\hline tamor & 1 & 1 & 1 & 1 & 1 & 1 & 1 & 1 & 1 & 1 & 1 & 11 & 0 & 0 \\
\hline kha pia & 1 & 1 & 1 & & 1 & 1 & 1 & 1 & 1 & 1 & 1 & 10 & 3 & 2 \\
\hline ta baek & 1 & 1 & 1 & & 1 & 1 & 1 & 1 & 1 & 1 & 1 & 10 & 2 & 1 \\
\hline duk sai & 1 & 1 & 1 & & 1 & 1 & 1 & 1 & 1 & 1 & & 9 & 1 & 1 \\
\hline kra bao hin & & 1 & 1 & 1 & 1 & 1 & 1 & 1 & 1 & 1 & & 9 & 1 & 1 \\
\hline lam jong & 1 & 1 & 1 & & 1 & 1 & 1 & 1 & & 1 & 1 & 9 & 0 & 0 \\
\hline pradu & 1 & & & & 1 & 1 & 1 & 1 & 1 & 1 & 1 & 8 & 1 & 1 \\
\hline tin tang & 1 & 1 & 1 & & & 1 & 1 & 1 & & & 1 & 7 & 3 & 1 \\
\hline tin nok & 1 & & & & & 1 & & 1 & 1 & 1 & 1 & 6 & 6 & 3 \\
\hline wa khao & & 1 & 1 & & 1 & 1 & 1 & & & 1 & & 6 & 1 & 1 \\
\hline nam choi & & 1 & 1 & & & 1 & 1 & & 1 & & & 5 & 1 & 1 \\
\hline pha yung & 1 & 1 & & & & & & 1 & 1 & & 1 & 5 & 1 & 1 \\
\hline ta baek lueat & & 1 & 1 & & & 1 & & & 1 & 1 & & 5 & 1 & 1 \\
\hline saen pun & & & 1 & & & & 1 & 1 & & 1 & 1 & 5 & 0 & 0 \\
\hline dimi & 1 & & & & 1 & 1 & & 1 & & & & 4 & 5 & 4 \\
\hline
\end{tabular}




\begin{tabular}{|c|c|c|c|c|c|c|c|c|c|c|c|c|c|c|}
\hline \multirow[t]{2}{*}{ PLANT NAME } & \multicolumn{11}{|c|}{ INFORMANTS } & \multirow[t]{2}{*}{ TOTAL } & \multirow[t]{2}{*}{ Binomial $^{1}$} & \multirow[t]{2}{*}{ Families $^{2}$} \\
\hline & A & B & C & D & $E$ & $\mathbf{F}$ & $\mathbf{G}$ & $\mathrm{H}$ & $\mathrm{I}$ & $\mathbf{J}$ & $\mathrm{K}$ & & & \\
\hline po & & & & & 1 & 1 & 1 & & & 1 & & 4 & 4 & 3 \\
\hline bora phet & 1 & & & & & 1 & & & & 1 & 1 & 4 & 2 & 2 \\
\hline phrik & & & & 1 & 1 & 1 & & & & 1 & & 4 & 2 & 2 \\
\hline mueat bai yao & & & 1 & & & 1 & 1 & & 1 & & & 4 & 0 & 0 \\
\hline khem khao & & & 1 & & & & 1 & & & 1 & & 3 & 5 & 3 \\
\hline kradai ling & & & & 1 & 1 & & & & 1 & & & 3 & 1 & 1 \\
\hline mueat pla sio & & & 1 & & & 1 & 1 & & & & & 3 & 1 & 1 \\
\hline sasu & 1 & & & & 1 & & & 1 & & & & 3 & 1 & 1 \\
\hline daeng dong & & & & & & 1 & & 1 & & & & 2 & 6 & 5 \\
\hline kra bao klak & & & 1 & & & & & & & & 1 & 2 & 1 & 1 \\
\hline kra bao ling & & & 1 & & & & & & & 1 & & 2 & 1 & 1 \\
\hline chom chuen kao & & & 1 & & & & 1 & & & & & 2 & 0 & 0 \\
\hline kuer tay dip & & & 1 & & & 1 & & & & & & 2 & 0 & 0 \\
\hline nam ka jorn & & 1 & & & & 1 & & & & & & 2 & 0 & 0 \\
\hline pra dong & 1 & & & & & & & & & & 1 & 2 & 0 & 0 \\
\hline wa jam joi & & & 1 & & & 1 & & & & & & 2 & 0 & 0 \\
\hline di ngu & & & & & & & & & 1 & & & 1 & 7 & 5 \\
\hline mueat & & & & & & & & & & 1 & & 1 & 5 & 4 \\
\hline som kop & 1 & & & & & & & & & & & 1 & 5 & 5 \\
\hline mueat khon & 1 & & & & & & & & & & & 1 & 4 & 3 \\
\hline po daeng & & & & & & & & 1 & & & & 1 & 4 & 2 \\
\hline sam phan ta & & & & 1 & & & & & & & & 1 & 4 & 2 \\
\hline ham ao & & 1 & & & & & & & & & & 1 & 3 & 3 \\
\hline khem & & & & 1 & & & & & & & & 1 & 3 & 3 \\
\hline kheng & & & & 1 & & & & & & & & 1 & 3 & 3 \\
\hline wa & & & & & & & & 1 & & & & 1 & 3 & 2 \\
\hline ko & 1 & & & & & & & & & & & 1 & 2 & 1 \\
\hline khi thao & & 1 & & & & & & & & & & 1 & 1 & 1 \\
\hline mueat som & & & & & & & & & & & 1 & 1 & 1 & 1 \\
\hline wa khi mot & & & & & & & & & & & 1 & 1 & 1 & 1 \\
\hline duk & & & & 1 & & & & & & & & 1 & 0 & 0 \\
\hline duk yai & & & & & & & & & & & 1 & 1 & 0 & 0 \\
\hline herd dong & & 1 & & & & & & & & & & 1 & 0 & 0 \\
\hline khai kao & 1 & & & & & & & & & & & 1 & 0 & 0 \\
\hline kuer daeng phun & 1 & & & & & & & & & & & 1 & 0 & 0 \\
\hline kuer fuk kao & 1 & & & & & & & & & & & 1 & 0 & 0 \\
\hline kuer houng sui & & 1 & & & & & & & & & & 1 & 0 & 0 \\
\hline kuer kao gerb & 1 & & & & & & & & & & & 1 & 0 & 0 \\
\hline kuer kaen teaw & & & & & & & & 1 & & & & 1 & 0 & 0 \\
\hline kuer suer kong & 1 & & & & & & & & & & & 1 & 0 & 0 \\
\hline kuer saen phun & & 1 & & & & & & & & & & 1 & 0 & 0 \\
\hline
\end{tabular}



Communities of Northeast Thailand

\begin{tabular}{|c|c|c|c|c|c|c|c|c|c|c|c|c|c|c|}
\hline \multirow[t]{2}{*}{ PLANT NAME } & \multicolumn{11}{|c|}{ INFORMANTS } & \multirow[t]{2}{*}{ TOTAL } & \multirow[t]{2}{*}{ Binomial $^{1}$} & \multirow[t]{2}{*}{ Families $^{2}$} \\
\hline & A & B & $\mathrm{C}$ & D & $E$ & $\mathbf{F}$ & $\mathbf{G}$ & $\mathbf{H}$ & $I$ & $\mathrm{~J}$ & $\mathrm{~K}$ & & & \\
\hline mueat kaeo & 1 & & & & & & & & & & & 1 & 0 & 0 \\
\hline nam luek lea & & & & & & 1 & & & & & & 1 & 0 & 0 \\
\hline pi phorn & & & & & & & & & 1 & & & 1 & 0 & 0 \\
\hline po kie kwai & & & 1 & & & & & & & & & 1 & 0 & 0 \\
\hline po kum & & 1 & & & & & & & & & & 1 & 0 & 0 \\
\hline po tan kao & & & 1 & & & & & & & & & 1 & 0 & 0 \\
\hline po tan yai & & & 1 & & & & & & & & & 1 & 0 & 0 \\
\hline phrik tong & & 1 & & & & & & & & & & 1 & 0 & 0 \\
\hline saen sam kae & & & 1 & & & & & & & & & 1 & 0 & 0 \\
\hline som soi & & & & & & & & & & 1 & & 1 & 0 & 0 \\
\hline som sui & & 1 & & & & & & & & & & 1 & 0 & 0 \\
\hline ta baek kao & & 1 & & & & & & & & & & 1 & 0 & 0 \\
\hline tom toi & & 1 & & & & & & & & & & 1 & 0 & 0 \\
\hline wa cha mod & & & & & & & & 1 & & & & 1 & 0 & 0 \\
\hline NAMES USED & 29 & 26 & 29 & 15 & 20 & 30 & 23 & \begin{tabular}{|l|}
24 \\
\end{tabular} & 21 & 24 & 22 & & & \\
\hline UNIQUE NAMES & 9 & 10 & 4 & 4 & 0 & 1 & 0 & 4 & 2 & 2 & 3 & 39 & & \\
\hline
\end{tabular}

1. Number of Latin binomials matched to this name in Smitinand (2001)

2. Number of families into which Latin binomials fall.

ment will be based the more exacting standard of secondary names. Differences in specificity of response might be the result of different skill level of the informants or the fact that some individual plants lacked many diagnostic characters that allowed them to be identified more precisely. In many cases, informants showed they were aware of many secondary names and sometimes supplied both primary and secondary names for some individual plants but, in other cases, used only primary names without further specification.

Some primary names appear to be applied to taxa more than one genera, or even family, according to the Linnaean system. The common primary name mueat represents an extreme case. Phinthong (1989), in his authoritative dictionary of the Isaan language, notes that the name is applied to "various types of bushes or trees, some with edible leaves, some used medicinally". In the plant list of Smitinand (2001) there are no less that 87 entries under this primary name, although most of them are associated with members of the genera Aporusa (Euphorbiaceae), Helicia (Proteaceae), Memeycylon (Melastomataceae) or Symplocos (Symplocaceae). In this study, three plants referred to as types of mueat by one informant were identified from voucher specimens as Memecylon umbelatum Burm. (mueat ae), Hydnocarpus ilicifolia King (Flacourtiaceae) (mueat kaeo) and Suregada multiflora (A.Juss.) Baill. var. multiflora (Euphorbiaceae) (mueat khon). Clearly the conception behind the local naming system either departs radically from the Latin binomial system.

All informants used a suite of eight names suggesting at least a core of shared vocabulary (Table 2). A further nine other names were used by a majority of the informants. There were only a few instances where particular infor-

Table 3. Three examples of plants identified with multiple secondary names.

\begin{tabular}{|l|l|l|}
\hline Example 1 & Example 2 & Example 3 \\
\hline mueat & po & wa \\
\hline mueat bai yao & po daeng & wa cha mod \\
\hline mueat khon & po kie kwai & wa jom joi \\
\hline mueat pla sio & po kum & wa khao \\
\hline mueat som & po tan kao & wa khi mot \\
\hline mueat ae & po tan yai & \\
\hline mueat kaeo & & \\
\hline
\end{tabular}




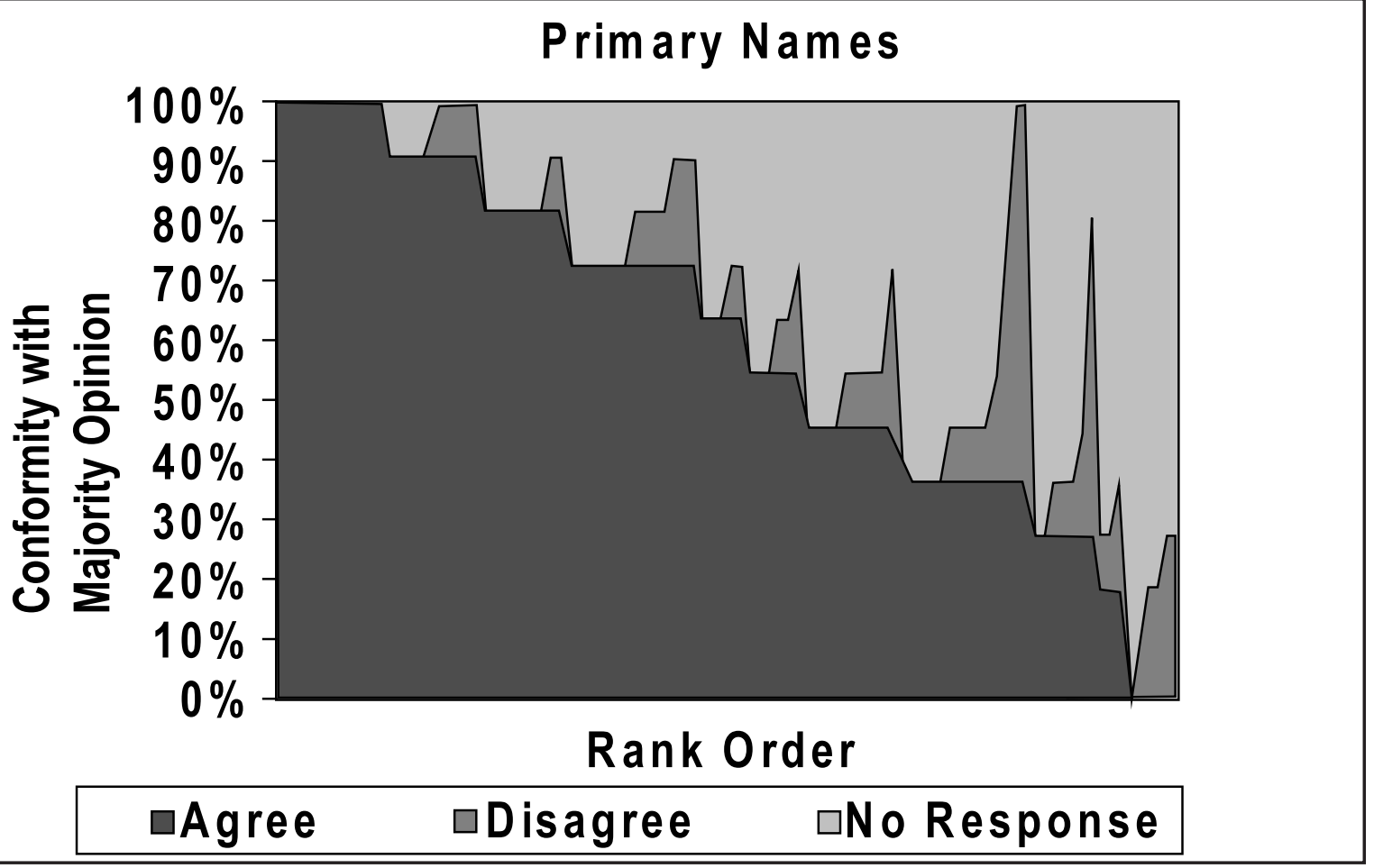

Figure 2. Degree of agreement among informants on common names of plants.

mants gave a name for plants that was consistently different from the majority and these are listed below.

\begin{tabular}{|l|l|l|}
\hline $\begin{array}{l}\text { Name supplied by } \\
\text { majority of informants }\end{array}$ & Alternate name & Informant \\
\hline kaen tao & ham ao & B \\
\hline mueat & khai khao & A \\
\hline kha pia & sam phun ta & D \\
\hline kra bao hin & kra bao klak & K \\
\hline
\end{tabular}

Of these names, Smitinand (2001) records that both the names kra bao hin and kra bao klak appear to be synonyms applied to Hydnocarpus ilicifolia King. In one instance several informants indicated that there were two generally accepted names for a plant (kom som and kom peow) and gave both. This situation is not surprising since there has been considerable immigration of people from other provinces and regions in recent decades. However, except in these few cases, there is no obvious evidence to suggest more than one distinct naming tradition among this set of informants.

Although there were many instances where informants gave no response, the majority of those who supplied names agreed about the primary name for almost all of the plants, but sometimes disagreed about secondary names (Figure 2). For eleven plants (11.5\%) representing seven different taxa, all informants named the plants and unanimously agreed on the primary name of it. For 49 plants $(51.0 \%)$ there was also complete unanimity among those who supplied names. Where there were differences of opinion about the identity of a plant, the majority of informants were in agreement. Those who disagreed with the majority also disagreed with each other. Figure 2 shows that, although some plants elicited only a small number of responses, there were only nine plants for which there was no majority opinion. It is to be noted that much of the disagreement was the result of informants not feeling sufficiently confident to supply any name for a plant and this is shown in the figure as "no response".

In the cases where individuals supplied names different from the majority (Figure 2), much of the disagreement focused on a few individual specimens and in some cases there was a very wide difference of opinion. This is illustrated in Figure 3 showing the numbers of different names applied to each of the 96 plants in the survey. As noted earlier 49 plants $(51.0 \%)$ were recognized by the same primary name. The level of agreement drops slightly to 40 plants $(41.6 \%)$ if the more exacting standard of agreement to the level of secondary names is applied. A small number of individual plants, only four, had more than four primary names applied to them. In the extreme instance, one specimen was identified by six different primary names by eight people (Figure 3 ). When secondary names are considered of course the level of disagreement rises somewhat but it is evident that much of the disagreement is at the primary level and not at lower taxonomic levels. 


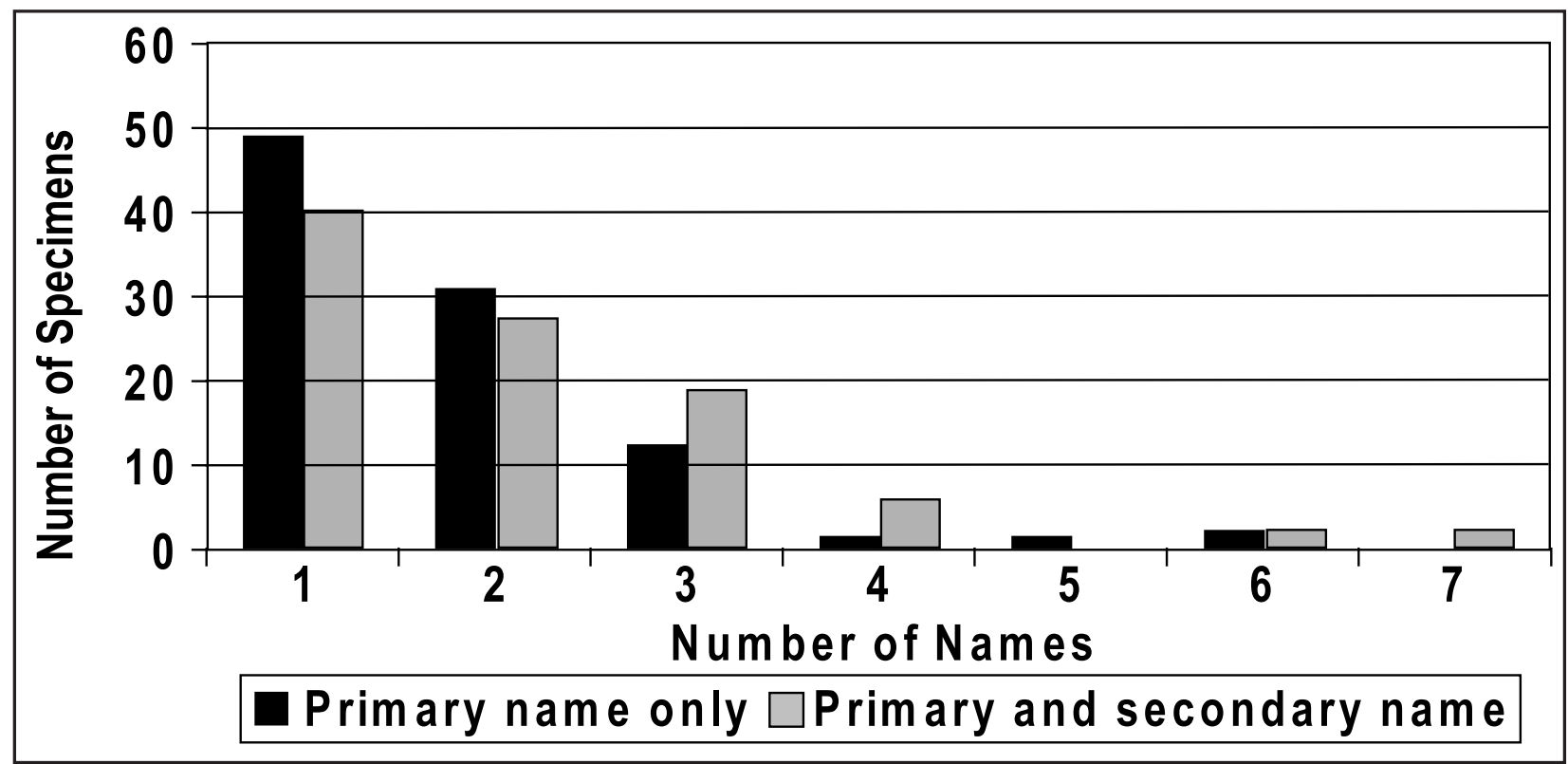

Figure 3. Numbers of different names applied to individual plant specimens.

Among the ten plants to which more than four different primary or secondary names were assigned, half were vines (kuer). This may indicate vines in the understory are particularly difficult to differentiate. In one case the vine may have been confused with the host plant in the recording of the data as the measured dimension of the plant does not accord with a vine habit.

One major source of uncertainty seems to lie in a set of 39 names that were recorded only once. Most informants gave at least one such singleton name that no other informant applied to the plants at the site. These names represent almost half of all those recorded.

A comparison of the extent to which individual informants agreed with each other was calculated by tallying the number of instances where they gave the same primary and secondary names for a particular plant. This is shown in Table 4, which displays the agreement score for all possible pairs of informants. The highest level of agreement was among informants $\mathrm{A}, \mathrm{J}, \mathrm{F}$ and $\mathrm{K}$ who all scored over 50 out of a possible 96 with at least one other person. When the total of all the scores for each informant are tallied, the same informants appear at the top of the rankings for scoring the highest amounts of agreement with all informants (Table 5). The lowest agreement scores all seem to be associated with informant $D$. His agreement with every other person was the lowest and all below 25 . Furthermore, he named the least number of plants and used the fewest number of names. This suggests perhaps he was the least knowledgeable of the group rather than representing a different linguistic or social tradition.

Table 4. Pairwise comparison of agreement between informants of name for each plant. The maximum possible value, representing complete agreement, would be 96. (Informants are identified by letter A through K).

\begin{tabular}{|c|c|c|c|c|c|c|c|c|c|c|}
\hline & B & C & D & E & F & G & H & I & J & K \\
\hline A & 32 & 31 & 21 & 36 & 52 & 42 & 46 & 44 & 53 & 57 \\
\hline B & & 27 & 18 & 28 & 33 & 30 & 29 & 29 & 32 & 26 \\
\hline C & & & 16 & 28 & 39 & 36 & 30 & 31 & 34 & 30 \\
\hline D & & & & 24 & 24 & 23 & 23 & 22 & 23 & 21 \\
\hline E & & & & & 41 & 39 & 39 & 35 & 40 & 36 \\
\hline F & & & & & & 47 & 46 & 42 & 54 & 51 \\
\hline G & & & & & & & 41 & 38 & 45 & 42 \\
\hline H & & & & & & & & 38 & 45 & 45 \\
\hline I & & & & & & & & & 40 & 41 \\
\hline J & & & & & & & & & & 51 \\
\hline
\end{tabular}


Table 5. Ranking of informants based on the overall degree of agreement with other informants. The value of "total agreement" was calculated by summing the number of instances where the name given for a particular plant coincided with the name given by other informants. The maximum possible value, representing complete agreement with all informants for all plants, would be 960 .

\begin{tabular}{|c|c|c|c|c|}
\hline Informant & Total \# agreement & \# plants & \# names used & \# unique names \\
\hline F & 429 & 78 & 30 & 1 \\
\hline J & 417 & 71 & 25 & 2 \\
\hline A & 411 & 96 & 29 & 9 \\
\hline K & 400 & 69 & 22 & 3 \\
\hline G & 383 & 61 & 24 & 0 \\
\hline H & 382 & 66 & 25 & 4 \\
\hline I & 360 & 60 & 21 & 2 \\
\hline E & 346 & 53 & 20 & 4 \\
\hline C & 302 & 65 & 30 & 10 \\
\hline B & 284 & 55 & 29 & 4 \\
\hline D & 215 & 37 & 15 & \\
\hline
\end{tabular}

There exist a number of important compilations of Thai plants names that have been recorded by botanists mostly associated with the Royal Forest Department of Thailand (Bunkerd 1982, Smitinand 1980, 2001, Vidal 1959, Winet 1940) and these have served as important tools for researchers. Typically local names are recorded when voucher specimens are made and noted on sheets in the Royal Forest Department Forest Herbarium and this is probably the source of much of the data found in the publications cited above. The province where these local names were recorded is indicated in most published lists. Of the 77 different names provided by informants of the plants in our survey site, we found that in 23 cases $(24.0 \%)$ the same local name is applied to more than one species defined in the Linnean system (Table 2). This is not surprising considering the great cultural and linguistic diversity of Thailand. In extreme cases, the name di ngu is applied to seven species in five different families and dean dong is applied to six different species in five different families. A total of 36 local names (46.7\%) given by informants were not found at all in these published lists. Of these names, all informants used three of them and a total of eleven were used by more than one informant suggesting they are in common local usage. Clearly the inventory of common names in the scientific literature is far from complete.

Voucher specimens were taken and identified independently with reference to existing herbarium materials. The Latin names so derived showed some agreement with the Latin names attached to local names in the literature (Table 6$)$. However, in only five cases $(18.5 \%)$ was there a match at the species level and in three of these cases the same common name was also applied to species in different families. There were six cases $(22.2 \%)$ where there were name matches within the same genus and two cases $(7.4 \%)$ of matches within the same family. In four cases $(14.8 \%)$ there were no matches except in different families.

\section{Conclusions}

Close knit and isolated groups might be expected to have a very coherent plant vocabulary that is generally understood and agreed upon and based on similar first hand direct observations. In contrast, within culturally mixed communities, or those that have strong social and linguistic connections to the wider world, one might expect more nomenclatural confusion because of differing shared experiences and exposure to a variety of naming traditions.

Locally recognized herbalists in a rural agricultural community in Northeast Thailand were asked to name the same tagged trees and vines in a forest. The results suggested they shared at least a core set of plant names that were fairly consistently applied even though one informant came from a village 200 kilometers from the others. There was no strong indication from the data of more than one naming tradition even though the region has recently received significant immigration from other parts of Northeast Thailand and elsewhere. One informant was a fairly conspicuous outlier who gave fewer responses, and used a smaller set of names, which suggested he might be less knowledgeable than the others.

Much of the total disagreement among informants took the form of non-responses, which is to say that some individuals did not feel sufficiently confident to attach a name to a plant and so, under the definition adopted here, they were considered to "disagree" with any who gave a name. In other cases, disagreement took the form of degrees of specificity. Informants may have agreed about the primary name but not the more specific modifier or secondary 


\section{Wester \& Yongvanit - Naming Consistency for Forest Plants in Some Rural Communities of Northeast Thailand}

TABLE 6. Comparison between the Latin names of plants identified from voucher specimens, the common names attached to them in the published scientific literature and the common names given by informants. Latin names cited are consistent with Smitinand (2001).

\begin{tabular}{|c|c|c|c|c|}
\hline \multirow[t]{2}{*}{ Latin names } & \multirow[t]{2}{*}{ FAM } & Smitinand (2001) & Informant & Match \\
\hline & & Common name & Name & Level \\
\hline Hymenopyramis cana Craib & VRB & kha pia & kha pia & species \\
\hline Sindora siamensis Teijsm. \& Miq. & CAE & ma kha tae & ma kha tae & species \\
\hline Suregada multiflora (A. Juss) Baill. var. multiflora & EPH & duk sai & duk sai & species \\
\hline Tinospora crispa (L.) Miers ex Hk.f Thoms. & MEN & bora phet & bora phet & species \\
\hline Vitex peduncularis Wall. ex Schauer & VRB & tin nok & tin nok & species \\
\hline Capparis micracantha DC ssp. micracantha & CAP & chai chu & sasu & genus \\
\hline Diospyros bejaudii Lecomte & EBE & i do & salak dam & genus \\
\hline Diospyros malabarica (Desr.) Kostel & EBE & ma khuea theun & $\operatorname{dimi}$ & genus \\
\hline Gardenia sootepensis Hutch & RUB & khai nao & khai nao & genus \\
\hline Markhamia stipulata (Wall) Seem. K. Sch var. stipulata & $\mathrm{BIG}$ & khae hua mu & khae pa & genus \\
\hline Memecylon umbelatum Burm. & MLS & mueat ae & mueat ae & genus \\
\hline Anogeissus acuminata (Roxb. Ex DC) Guill. & CMB & ta khian nu & sang kham & family \\
\hline Uvaria rufa BI. & ANN & ting tang & tin tang & family \\
\hline Anogeissus acuminata (Roxb. Ex DC) Guill. & CMB & mak piak & ta baek & no match \\
\hline Hydnocarpus ilicifolia King & FLA & kra bao hin & mueat kaeo & no match \\
\hline Pterocarpus macrocarpus Kurz & PAP & pradu pa & pha yung & no match \\
\hline Suregada multiflora (A. Juss) Baill. var. multiflora & EUP & mueat lot & mueat khon & no match \\
\hline Aporusa sp. & EUP & & kai khao & no record \\
\hline Bauhinia sp. & CAE & & daeng phun & no record \\
\hline Colona flagrocarpa (Cl.) Craib & TIL & thao & kean tao & no record \\
\hline Combretum latifolium BI. & CMB & kae dam & kao gaaeb & no record \\
\hline Dalbergia ovata Grah. ex Bth. & PAP & du laeng & pradong & no record \\
\hline Diospyros buxifolia (BI.) Hiern & EBE & lambit (D. ferrea ) & lam jong & no record \\
\hline Microcos paniculata L. & TIL & khom & $\begin{array}{l}\text { kon som/ } \\
\text { kom preow }\end{array}$ & no record \\
\hline Passiflora edulis Sims & PAS & kra thok rok farang & fuk kao & no record \\
\hline Rothmannia winitii (Craib.) Brem. & RUB & mak mo & ta mo & no record \\
\hline Strychnos rupicola Pierre ex Dop. & LOG & khi ka khruea & seur kong & no record \\
\hline
\end{tabular}

name. However, there remained a significant number of cases where distinctive and apparently unrelated names were applied to the same plant. A small number of individual plants accounted for most of this disagreement. In one case a single plant was given six different primary names by eight different people. These plants given many different names tended to be small, immature individuals that often lacked diagnostic parts or they were vines. One common vine (borra phet) however, was consistently recognized and it is notable that this is a common and useful medicinal plant with a distinctive stem. Otherwise vines tended to be the plants where there was the greatest divergence of opinion. The level of disagreement among local experts in this study demonstrates the desirability of obtaining more than one opinion about the local name for a plant. 
Of the common names collected in this study, a large proportion $(46.7 \%)$ was not found recorded in the standard reference sources for Thai plants. In $24.1 \%$ of the cases the names were applied to more than one species, often in different families. This clearly suggests different naming traditions exist within the culturally and linguistically diverse regions of Thailand and illustrates the danger of attempting to use the standard reference works in botany to assign Latin names to plants that have been identified only by their common names.

Common names can be a useful aid to help link to Latin names for a plant as long as voucher specimens are taken and checked against diagnostic descriptions or herbarium materials identified by competent taxonomists. In this study only $23.4 \%$ could be linked through standard references to single Latin binomials, but $29.9 \%$ of the names were linked to more than one binomial, often in different families. These many false links are the reason why plant list dictionaries can be so badly misused and why the practice of simply looking up Latin names from common names should be discouraged.

\section{Acknowledgements}

The authors would like to thank the informants whose knowledge was that basis of the data for this study, Wiroj Chamsaeng for his help in the field, James Maxwell, for identifying our voucher specimens.

\section{Literature Cited}

Berlin, Brent. 1992. Ethnobiological Classification: Principles of categorization of plants and animals in traditional societies. Princeton University Press, Princeton, N.J.

Bunkerd, Saad, Jaray Sadaakorn \& Tippan Sadaakorn. 1982. Vernacular Names of Thai Plants. Forestry Department, Kasetsart University, Bangkok.

Gardner, Simon, Pindar Sidisunthorn \& Vilaiwan Anusarnsunthorn. 2000. A Field Guide to the Forest Trees of Northern Thailand. Kobfai, Bangkok.

Martin, Gary J. 1995. Ethnobotany: A Methods Manual. Chapman \& Hall, London and New York.

Phinthong, Preecha, 1989. Isan-Thai-English Dictionary. Siritham Press, Ubon Rachthani, Thailand.

Smitinand, Tem. 1980. Thai Plant Names: Botanical names-vernacular names. Krom Pamai, Bangkok.

Smitinand, Tem. 2001. Thai Plant Names. Revised edition. The Forest Herbarium, Royal Forest Department, Bangkok.
Yongvanit, Sekson \& Thongchan Homnetra. 1993. Changes in Landuse in National Reserve Forest Northeast Thailand: A case study of village settlement in Dong Mun National Reserve Forest. Regional training workshop for technical and extension level agroforestry trainers in Asia Pacific, 14-27 November, Khon Kaen University, pp. 1- 9.

Vidal, Jules. 1959. Noms vernaculaires de plants (Lao, Mèo, Kha) en usage au Lao. Bulletin de l'Ecole Française d'Extrême-Oriente, Tome 56. Fasc. 2.

Wester, Lyndon \& Sekson Yongvanit. 2006. Farmers, Foresters and Forest temples: Conservation in the Dong Mun Uplands, Northeast Thailand. Geoforum 36:735-749.

Winet, 1940. Siamese Plant Names. Royal Forest Department, Bangkok. 